\title{
Civic Engagement And Islamic Ethos In Pakistan
}

\author{
Sumrin Kalia \\ \& \\ Khalid Mahmood Iraqi \\ Department of Public Administration \\ University of Karachi
}

\begin{abstract}
The purpose of this article is to investigate the idea of civic engagement and Islamic ethos in the context of Pakistan. Since Pakistan's society and concept about citizenship are based on the premise of religious nationalism, therefore, Islam forms the basis of people's perceptions and belief of public life. There has been a lot of change in the conceptions of societies throughout the world after modernization and large-scale spread of scientific and technological knowledge. Several nations have redesigned their lifestyle in the wake of modern sciences as they realize the significance of new discoveries and innovative advancements. Ethical value of religious teachings stands as a reality. However, change is always the order of the day. The peoples accepting change manage to sustain with success and dignity. Accordingly, an increasing emphasis on social change and development, human rights and democratic values, combined with declining performance of successive governments in public service delivery, demands a well-informed public splinted and engaged citizenry in Pakistan. In the contemporary world civic engagement is about promoting the quality of life in a community in a real term rather than as symbolic values. The various successive governments in Pakistan have failed to address this issue. In a true context whether we take Islamic or the western perception, the welfare of the people is the corner stone of governance which demands a very realistic balance between the concepts of people and the principles of management of public life.
\end{abstract}

Keywords: Civic Engagement, Democratization, Fundamentalism, Sharia Law, Social Change.

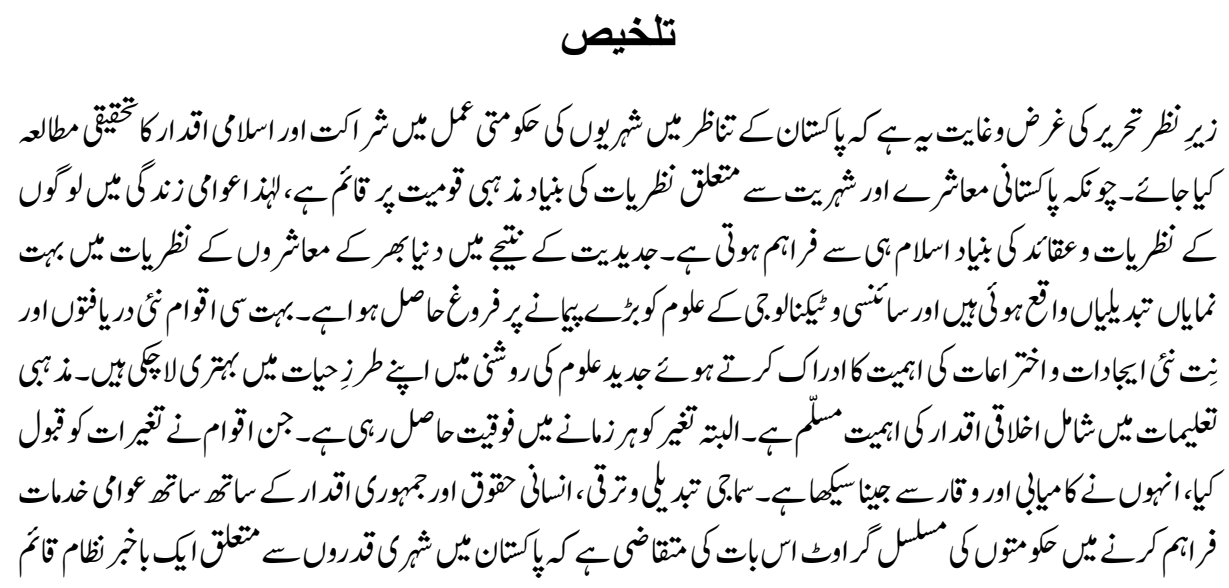




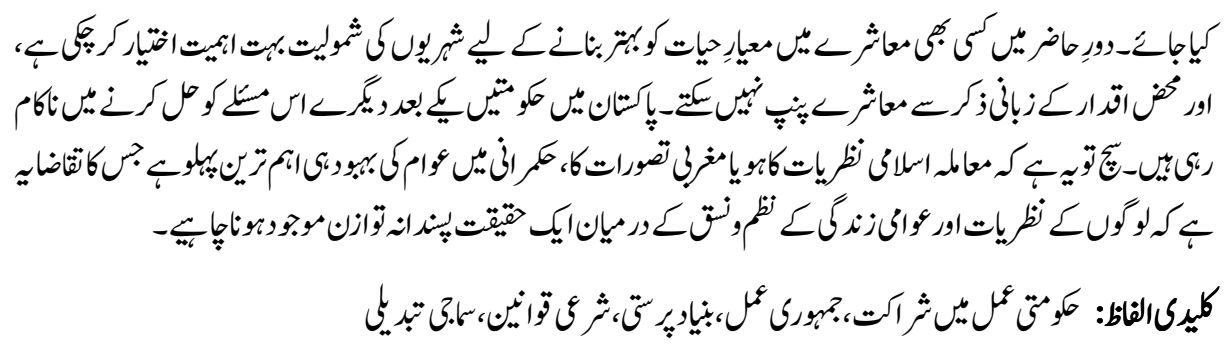

Active citizen involvement and a dynamic civil society are crucial for effective and sound public sector. The idea of Civic engagement has gained considerable importance as the world faces new political conditions and the citizens' demands and expectations change. Civic Engagement describes how an active citizen participates in the life of a community in order to improve conditions for others or to help shape the community's future. Civic Engagement can take a number of different forms, which may include conventional forms like voting, election campaigning, etc. and non-conventional forms which occur outside electoral practices e.g. signing petitions, participating in political demonstrations, etc. It also entails diverse types of activities, including working collectively to solve community problems, belonging to community organizations, attending meetings about issues of concern, volunteering, making donations to charities, etc. It may even include involvement in a range of different forms, such as paying attention to the news media (newspapers, television, magazines, radio, Internet), having political or civic knowledge or viewpoint, and holding opinions about and attitudes towards political or civic matters. Civic Engagement means working to make a difference in the civic life of our communities and developing the combination of knowledge, skills, values, and motivation to make that difference. It means promoting the quality of life in a community through both political and non political processes. (Eds. Tina Nabatchi 2012).

Pakistan's social structure has witnessed major shifts in the last few decades. The dynamics of political atmosphere, struggling democracy, changing religious proclivities have remained key factors in our perceptions of social interactions and public lives. An increasing emphasis on social development, human rights and democratic values, combined with declining performance of successive governments in public service delivery; demands a well-informed, public spirited and engaged citizenry in Pakistan. Morally and civically responsible citizens, who can recognize themselves as a members of a larger social fabric result in increased public participation in social, communal and political lives. They also serve to develop connections amongst each other, issues, institutions and the political system.

Pakistan's society and concepts about citizenship are unique as it's very creation was based on the premise of religious nationalism. Islam forms the basis of people's perceptions and beliefs of public life. The foregrounding of religious identity and privileging of Islam has had a far-reaching impact on notions of citizenship. Although Islamic symbols and Muslim 
ideology were central to the creation of Pakistan it was never intended to make it a theocratic state. This explains why, despite developing a collective based on religious commonality, Islamist parties forging Sharia law have never been able to establish government in Pakistan. However on the social front Islam has served as a sanctuary to the working class which has been disillusioned by the prevailing state of affairs. Islam has a hegemonic impulse in the wider society in the sense that it is seen as a complete code of life making it a dominant factor in social lives. This religious sentiment has been exploited by the state in an effort to gain legitimacy. During the 1970's and 80's General Zia's proreligious laws led to a growth of fundamentalist organizations. This action was reversed post 2000, by General Musharraf with the celebration of the 'moderate' Muslim. These shifting religious priorities, failure of democratic regimes together with sectarian and ethnic fault lines have resulted in a confused, skeptic and disengaged citizenry. Pakistan continues to be a society contested between two sets of sentiments and ideals, nationaldemocratic versus puritanical-Islamic. (Qadeer 2006) Each of the two themes accommodates a wide range of interpretations, models, and goals. Thus, Pakistan remains a country of divergent visions and commitments about its national identity and goals.

This socio-religious polarization manifests itself in the political spectrum. Politically, Pakistan has remained very unstable. In the past sixty seven years Pakistan has seen twenty-five governments, including; sixteen elected or appointed prime ministers, five interim governments and thirty three years of military rule under four different leaders. Excluding the military and interim governments, the average life span of a politically elected government has been less than six years. Despite being subjected to long spells of authoritarian rule characterized by martial law, the idealism and struggle for an accountable politico-economic order at different levels has never disappeared. The interest in electoral process however has waned due to this instability. . This is evident in the voting behavior as the turnout has remained persistently less than $60 \%$ in the entire electoral history of the country. (Figure:1) This disengagement has had a impact on the quality of democracy of the country.

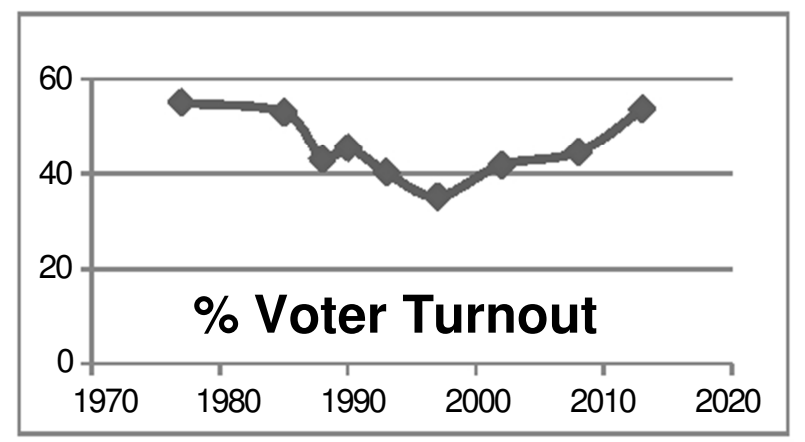

Figure: 1 Percentage Voter Turnout in Pakistan

Source: International Institute for Democracy and Electoral Assistance (International IDEA) 
While active participation in elections remains one of the important venues for citizen input, an increasing global tendency to shift power and responsibility to the profit and non-profit sector from the governments has dampened the resonance of traditional politics. The not for profit sector popularly termed as the third sector has emerged as an important means of channeling citizens' demands. Voluntary associations are expected to connect citizens to the political sphere while serving as a vehicle to prevent 'the retreat of individuals into their private lives'. Particularly in case of countries like Pakistan where the transition to democracy is recent, there is an increased emphasis on the role of civil society in strengthening democracy. As Norton maintains that the democracy is not 'the contested elections or the secret ballot but civil society where associations, clubs, unions, federations, parties and groups come together to provide a buffer between state and citizen' (Norton Spring 1993). The 'neo-Tocquevillean' studies have focused on organized groups of civil society as a surrogate measure of associational life and have argued that the disposition of individuals to voluntary organizations produces a more cooperative culture which in turn results in a more effective government. (Goldberg 2001) Several components are involved in promoting a sense of collective belonging. From fostering a sense of national engagement to bringing closer connections between people of diverse class, races and regions. These all are possible when people are more engaged in their public lives and mutually share interests, purposes and values. In Pakistani society Islam acts a defining factor of public lives. It provides a common ground to people to engage and mutually share interests and maintains its domination in social and political lives. Islam has driven people to engage in decisive dialogues about important public issues. It's influence on state and society has made it a significant instrument which drives communication among diverse groups of citizens, public officials and civic leaders. Below I have tried to explore the patterns of civic engagement in Pakistan by discussing the evolving nature of the civil society, impact of Islam on the civic engagement and the resultant influence on political and social lives in Pakistan.

\section{Civil Society in Pakistan}

Social lives in Pakistan are rooted in primordial ties, with the institutions of family, tribes and ethnicity defining an individual's place in the society. While these institutions form the basis of an individuals' identity; the presence of collective action in communities, associations and organizations in Pakistan is equally evident. Civil society in Pakistan, is a wide concept which includes, non-state and non market citizen organizations, initiative, networks and alliances. It includes diverse communal activities that regulate civic life, initiate community action, and counterbalance the excesses of state.

The beginning of civil society in Pakistan can be traced back to 1948 when the voluntary organizations were set for refugee rehabilitation. Since then there has been a growth in the activities of the civil society in education, health and women empowerment, however 
it was not until the 1980's when real momentum was noticed in activities of civil society. From, service delivery, Islamic education, advocacy, civil rights activism to community and neighborhood improvement a robust growth was seen in the number of civil society organizations. Today the civil society of Pakistan encompasses a broad range of Non State actors, including NGOs, CBOs, coalitions, faith-based organizations, professional associations, trade unions, labor unions, citizen groups, and voluntary organizations. They can be small voluntary organizations dependent on donations from their communities or well-established CSOs that employ full-time professionals.

In the first two decades the civil society was largely limited to an oppositional role usually led by literary clubs, bar councils and student unions. As Qadeer notes that the event that marked the threshold points in the evolution of civil society in the country was anti-Ayub agitation in 1969. New interests and social classes had developed in the form of traders, industrialists and labor unions. (M. Qadeer 1997) A fallout of his economic policies coupled with the war of 1965 mobilized large sectors of civil society. In March 1969, the port city of Karachi, which comprised 40 percent of Pakistan's industrial capacity, was brought to a standstill by labor strikes. (Noman 1990). A wide spread agitation, political fiasco and constitutional deadlock eventually resulted in the dismemberment of East Pakistan in 1971. The democratic regime of Bhutto saw an increased activity of Islamist factions. His socialist inclinations were instrumental in prompting Jama'at e Islami a prominent Islamist party towards political confrontation. Industrial and business interest groups upset with his nationalization policies joined the opposing political forces. Despite Bhutto's efforts to abate the crises by co-opting Islamist, the impasse led to Zia's military coup. General Zia, seeking political legitimacy, was quick to make a state-sponsored Islamization program the mainstay of his rule. Zia curtailed the moderate sentiments and used power to crush any political dissent.

Since the 1970's social life in Pakistan has been dominated by two penchants, Islamization of the public space and modernization of the private space and economy. Both these proclivities have had an influence on the civil society of the country. Civil Society activity greatly increased during this time, however the growth was twofold; the rise of moderate advocacy groups and service providers coupled with an increase in Faith-based organizations which can be appropriately termed as 'Islamic Organizations'. The religious emphasis during Zia regime led to the growth of the madrassa education, which became a hotly debated issue post 9/11. The data collected on the growth of Madrassa education shows that the enrolment in religious education saw an increase in the period after 1980. (Andrabi 2005). This trend was even obvious until 2002 when a study conducted by SPDC noted that the leading activity in the non-profit sector was religious education (SPDC 2002). A recent brooking center study noted that the Madrassas make up the largest network of NGOs in the Muslim World (Ali Aug 2009) The rise of moderate segment of the civil society was evident in a considerable increase 
in the number of advocacy groups. A significant growth of advocacy oriented NPOs came about during a period when civil liberties were non-existent. The Non Profit Sector got actively involved in creating awareness and articulating civil society's response. Trade and student unions, advocacy oriented NGOs and women's fora were most prominent in these efforts. The Human Rights Commission of Pakistan, Pakistan Institute of Labor Education and Research, Women's Action Forum and Ansar Burney Trust are products of 1980's. (M. A. Iqbal 2004) The period also saw the growth of civil society in roles of service delivery. Some large nonprofit organization came into prominence. These included the Aga Khan Rural Support Program (AKRSP), Orangi Pilot Project (OPP) etc. Edhi Trust, a welfare organization, which was primarily based on indigenous resources and was established in 1951, emerged as legendary social welfare organization due to its tremendous contribution in the area of emergency relief and rehabilitation. ${ }^{1}$

The 1990s Islamic Resurgence worldwide led to the growth of 'Islamic Civil Society' which paralleled, surpassed and often supplanted the frequently frail institutions of secular civil society (Huntington 2002). In the form of student unions, youth organizations, madrassas, mosques, seminaries they continued their role in educating the poor, disseminating zakath (Islamic donation) and preaching Islamic ideology. This phenomenon empowered and emboldened Islamists and Ulema activists who articulated an Islamic discourse of power. The principal Islamic actors were the Jama'at e-Islami, (Islamic Party) Jami'at-e-Tulbah,(Student wing of Jama'at-e-Islami), Jami'at-e-Ulem-ePakistan (Ulema of Pakistan Union), Jam'iat-e-Ulema-e-Islam (Ulema of Islam Union) and a movement Nizam-e-Mustafa (Order of the Prophet). This Islamic Civil Society during Bhutto's regime had been able to exert considerable pressure on the government leading to the enforcement of laws like, Anti-Ahmadiya law, banning of alcohol, gambling etc. During Zia's period these groups were largely supported by the state which sought to establish the authority of the state and to facilitate its greater reach in the society. The Hudood Ordinance, Zakat and Ushr Ordinance, and the blasphemy law among others were a product of this era. Islamic civil society groups are well organized and have access to resources through donations. Their religious endorsement renders them greater influence and provides legitimacy.

By the early 2000 this dual-existence of the Pakistani civil society was more pronounced. The backwash of Afghan war, Talibanization and governance failure made important contributions in making some of Islamist groups breeding grounds for extremism, militancy and sectarian violence. Charitable organizations with ties to radical groups exploit poverty as a recruitment tool. Musharraf's enlightened moderation delegitimized extremism in ideological sense, however its execution was deficient. His steps like Madrassa regulation campaign and banning of key militant groups faltered owing to his alliance of political expediency with Islamic parties. A large number of militant groups spawned across the country. (Haider 2011) 
Meanwhile, this period also saw a growth of moderate segments of the Civil Society as evidenced by the lawyers' movement. The prolific media and the urban middle class vehemently rejected extremism. Campaigns like 'Yeh Hum Naheen' (This is not us) were a public denunciation of radical Islam. A primary and indispensible aspect of the civil society is autonomy from the state, however, it does not necessarily imply that the civil society is in conflict with the state. Civil Society organizations may work in harmony with the purpose of the state, but they may also act an independent social force to keep a check on the state's abusive or undesired use of power. Ernest Geller for example argues that, "Civil Society is that set of diverse non-governmental institutions which is strong enough to counterbalance the state, and whilst not preventing the state from fulfilling its role as keepers of peace and arbiter between major interests, can nevertheless prevent the state from dominating and atomizing the rest of society."

However in case of Pakistan the moderate segments of Pakistan's civil society do not show the capacity to counter the overarching influence of the state in the lives of the people. The long autocratic regimes stunted the evolutions of the civil society and it has been largely depoliticized. The elected governments that followed Zia adopted a generally supportive attitude toward civil society organizations, especially those providing social welfare services. However they too made considerable efforts to curb civil society activities, for example, the NGO bill that was proposed in the parliament in 1996 as an attempt by the government to bring the nonprofit sector directly under its control and regulation. (Aisha Ghaus-Pasha June 2003). Despite increasing contributions to the provision of community services, NGOs are not capable of effectively igniting social movements or political mobilization. This was particularly evident in 1999 when prominent NGOs and media welcomed Musharraf's who ousted Nawaz Sharif's government. This inability also arises from the dominance of personalized and clientpatron networks in the social and political lives in the country. As Fukuyama notes that certain elements of civil society can also be described as interest groups trying to divert public resources to their favored causes. There is no guarantee that self-styled public interest NGOs actually represent real public interest. (Fukuyama 2001). Throughout the history of Pakistan, the state, both in democratic and military regimes has accumulated power from elite alliances, patronages which are in control of the distribution and access to power in the country. The political alignments and activities of Pakistani civil society have not always been so straightforwardly beneficial to the larger project of democratization. Commenting on the role of Civil Society during the Musharraf era, Akbar Ziadi noted;

"Far from challenging the state, a number of Pakistani NGOs have become the state's partners, to the mutual benefit of both. Development NGOs that emerged to fill gaps left by government failure now serve as official "advisors" to various state institutions, gaining publicity, credentials, and lucrative contracts in the process." (Ziadi 2008) 
The case of politically elected governments is similar. Dominated by narrowly-based political elite that was feudal or tribal in origin and oriented to more benefit than policy, their patronage is essentially about recruiting and managing familial and clan networks. As a result, the secular elements of civil society have remained ineffective in exerting any political pressure and have rather existed in a symbiotic relationship with the state. The significant role played by the civil society in welfare activities and public service is an encouraging sign. The SPDC study noted that there were 56,000 registered organizations in Pakistan with an inactivity rate of 53 percent, leaving approximately 30,000 active and registered CSOs. A statement by the Minister of Social Welfare and Special Education in 2010, estimated that the there were approximately 100,000 NGOs and community-based organizations (CBOs), 60,000 to 70,000 of which were registered. The rise of the educated urban class, support from international community and an increase in political and intellectual resources available, have resulted in an enhanced momentum in growth of Civil Society Organizations. In the last few years there has been a considerable improvement in the civil society activity. In 2011, a study commissioned by USAID estimated that there are over 30,000 active organizations out of which half work in education and $18 \%$ focus on civil rights and advocacy, while the rest work in social services, health, culture or recreation. According to the report the civil society in Pakistan has fairly well developed advocacy capacity (USAID 2011). A significant contribution of International NGOs like UNDP is notable which sought to bridge the gap between state and the society and were largely motivated towards the attainment of Millennium Development Goals. However their reach in Pakistan's social sphere has been limited. The civil society is largely depoliticized due to long episodes of autocratic rule, suppression of characterized by the forceful suspension of dissent. While civil society has witnessed dramatic growth in its organizational diversity since the mid-1980s, the non-state sector has yet to emerge as an independent, legally protected public realm of associational and civic activity (Shah 2004)

In contrast the Islamic Civil Society in the form of organizations like Jam'at ud Dawa and many others have been relatively successful in both humanitarian services, public mobilization and policy advocacy. Many Islamic organizations provide educational and welfare services to the poor strata of the society who cannot afford to pay for food education and housing. In a study of the evolution of Pakistani civil society Qadeer noted that in terms of influencing the civil society the only non-governmental, non-profit organizations which exercise considerable control over people's behavior and mobilize communities for their causes are Madrassahs. This hasn't changed much since the 1990s as seen in 2013 and 2014 when cleric based in Canada Dr. Tahir ul Qadri and the founder of a network of Islamic schools Minhaj'ul Quran, was able to stage large scale protests. Notably too, religious institutions and causes boast a 94 percent share of the contributions made by private indigenous philanthropists annually (AKDN 2000). In terms of policy advocacy they act as the only effective mediating institution between the 
state and society. They have pressed for pro-Islamic legislation and have been placated and abetted by the state for political expediency. The Islamic Civil Society in a pursuit of gaining political power, and the state for either getting legitimacy or forwarding the security agenda have collaborated with each other thereby reducing the capacity of the moderate segments of the civil society. Consequently, the balance of power between the secular and the religious is clearly tilted in favor of the latter. This is particularly evident in the case of blasphemy law where several extra judicial killings have been largely ignored by the state.

The next section further elaborates Islamic dominion that perpetuates the society and how it influences the political and social engagements in Pakistan.

\section{Islam as a Path to Civic Engagement}

For centuries Islam has remained a model of public order as well as personal ethics for Muslims around the world. It is culturally, politically and economically institutionalized and has been adapted to new social arrangements of Muslim societies. (Kamali 2001) Islamic ideology and its virulent schism has had a profound impact on the socio-political landscape of Pakistan. Islamism revivalism has systematically mixed religion and politics and faith with social action. It established groups and communities and their institutions that enjoyed a significant degree of autonomy from the state. Mosques have been centers of community networks and inculcated a sense of belonging to the Muslim Ummah (Nation). Islam served as a common identity in an ethnically and culturally diverse society and has been able to transcend ethnic and linguistic divides. Many sociopolitical organizations aiming proselytism of Islam have gained deep roots in Pakistani society. Jam'at-e-Islami is one of the oldest and most influential of the Islamic revivalist movements and the first of its kind to develop an Islamic ideology, a modern revolutionary reading of Islam, and an agenda for social action to realize its vision. (Nasr 1994) Mawdudi's (the founder of Jam'at) puritanical views disseminated through books, pamphlets and speeches appealed to the newly rising middle class. Jama'at's mission was to reform the lives and minds of individuals to turn them into pious men and women. Jama'at-e-Islami attracted a wide social base through its student organizations, lawyers' circles, Islamic labor unions and literary clubs, etc. For decades, it has dominated student union elections in universities and colleges who serve as envoys of Jama'at's message in their professional lives. These segments are the driving wedge of Islamic revivalism in Pakistan (M. A. Qadeer 2006). This revivalism proliferated the society and numerous other religious organizations sprung up in the country. A particularly interesting case is Alhuda International. It is women's socio-religious organization which was founded by Dr. Farhat Hashmi. Both her parents were members of Jam'at and she attended the Dars (sermons) of the Jama'at. Alhuda began in 1994 as an Islamic school for women, but it has quickly found inroads into the middle and upper classes of urban areas. Sadaf Ahmad 
has comprehensively studied the profound changes this organization has caused in the lifestyles of these women. She notes;

'The changes that take place as a result of this cultural production are visible on a number of different levels. They are,..., visible in women's changed attire, as they begin wearing hija ${ }^{-}$bs and $\mathrm{aba}^{-}$yas in public. This is a form of purdah or veiling that is not indigenous to Pakistan, but is rather an Arab import. Shops have now begun selling ready-made aba $^{-}$yas along with the more traditional chadors". (Ahmad 2008)

These women have successfully engaged each other in social dialogue and have attracted a large base of women activists are who are not only influencing mindset of society as a whole, but have also collectively engaged in philanthropic and welfare works. This social and cultural transition is indicative of the fact that civic activities in Pakistan are largely dominated by Islam.

The World Values Survey in 2012 reveals that out of 1200 respondents, among those who reported as active or inactive members of various organizations; the association with religious organizations was the highest

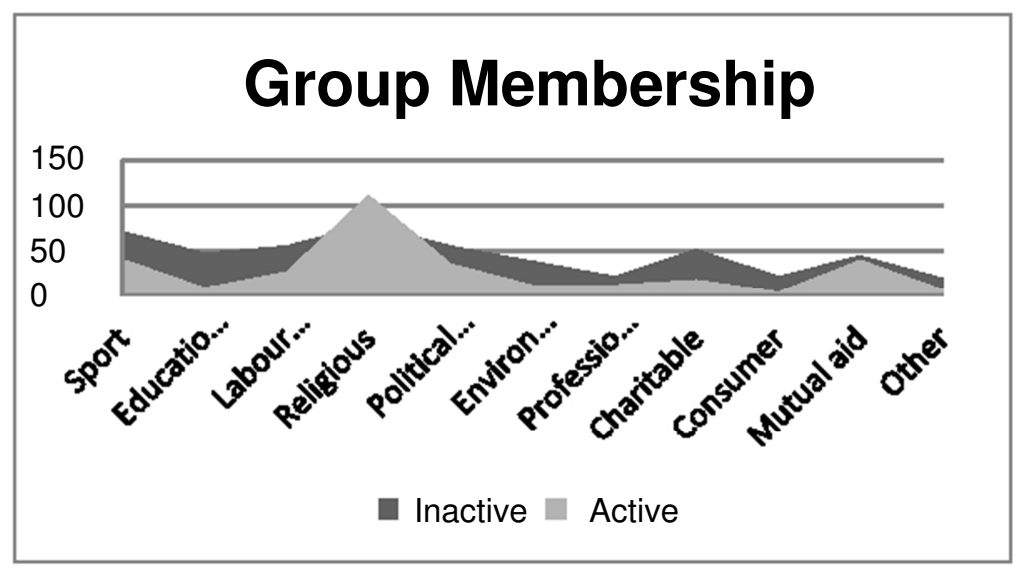

Jama'at-e-Islami has developed important connections in the lower and rural classes through its charitable work. Al-Khidmat Foundation, Jama'at's charitable wing was very active in relief work during the 2005 Earthquake as well as 2010 floods. According to JI's leaders, volunteers working under the auspices of Al-Khidmat provided aid to at least half a million flood victims. Similarly Minhajul Qu'ran schools run by the Pakistan Awami Tehrik (People's Movement), combines modern education with the option of specializing in Islamic studies.

Apart from the many social organizations that can be categorized as Islamic, based on 
their explicit emphasis on Islamic teachings, many other organizations, with an overt aim of philanthropy and humanitarian aid are fueled by altruistic teachings of Islam. Acts of humanitarianism are essential element of religious practice for Muslims. Quranic texts and hadiths in a persuasive manner encourage charity works. Humanitarian work for a Muslim is a way of receiving help from heaven, of erasing sins and of meriting Paradise. A study conducted on Religion and Development noted that that in the Pakistani context it is often difficult to identify an organization as an 'Faith Based Organization', because religion, especially Islam, underlies the motivations and activities of many welfare organizations - even those that do not explicitly identify themselves as Islamic organizations. Examples of such organization include the Edhi Foundation and the Aga Khan Development Network, both of which identify themselves as Muslims and admit religious exhortation as a motivating force however they do not explicitly classify themselves as Islamic. (M. Asif Iqbal 2008). This observation suggests that Pakistanis continue to show an inclination towards considerable religiosity while upholding progressive ideals. In this, they reflect the distinctive 'devout Muslim's identity', where their commitment to Islam has 'a deep integrated place in their self identity' but also upholds 'a fundamental commitment to modernity'. These difference can be explained by the duality of society referred earlier, which separates the 'modern' segments of Muslim polity from the 'Islamist' or 'fundamentalist' ones. However this absolute dichotomy does not reflect the aspirations of the majority of people in Pakistan who do not support religious fundamentalism or manifestly espouse supposedly anti-religious secular values (Nasr 2009). A more appropriate explanation is given by Kamali who describes them as 'quasi-modern' and 'quasi-traditional'. This means that the quasi-modern is not a stable modern society which can be compared to its Western counterparts, nor is the Islamic society purely traditional or fundamentalist. (Kamali 2001). This suggests that Islam cannot be compartmentalised or seen as an 'optional extra' for social welfare. The moral values of Islam can be harnessed to gain the larger benefit of community wellbeing. This, however, continues to be ongoing struggle owing to the contested nature of Islam.

The shifting religious priorities echoed in the political atmosphere of the country. Bhutto had faced growing agitation in the form of 'Nizam e Mustafa' movement that led him to give in to the demands of Islamization. General Zia, wary of the ethnic tensions and seeking legitimacy appealed to Islam as a means to bring stability to Pakistan. He took up the Islamizaton of the country, for reasons of expediency and to construct a state ideology. Islamic penal code and Islamization of judiciary were carried out and an increased observance of religion in the public sphere was mandated. The regime also provided financial support to religious seminaries which gave it control over these entities and also fulfilled the agenda of conveying state ideology to the masses. (Nasr, Islamic Leviathan; Islam and the Making of State Power 2001) This Islamization failed in its intended outcome of Islamic solidarity, social control and the uprising of extremist elements, rise in sectarian violence and ethnic tensions further divided the nation. Islam 
however continued to be important in political arena, however pragmatism dominated political decisions. As Nasr notes that the return of democracy after Zia gave birth to the Muslim Democrats, who in contrast to Islamists, exist in middle of the sharia-secularism continuum. They do not look to Quran for specific contestations of Sharia law, however they believe that Islamic teachings should inform public policy. In Pakistan political parties, Pakistan Muslim League Nawaz and Pakistan Tehreek-e-Insaad have gained support as Muslim democrats as they leverage aspects of religious ideology and culture to mobilize, recruit, and campaign in electoral contests. On the other hand parties like Jam'at-e-Islami, and Jam'iat-e-Ulema-e-Islam are Islamist parties explicitly supporting Islamic Sharia. They seek to empower religious leaders and base citizenship on religious affiliation. Despite having a common aim the Islamist parties differ largely in their interpretation of Sharia and Islamic laws. In the recent past these parties have shown political opportunism forming alliances among themselves (formation of Muttahida Majlis-e-Amal) as well as the left-wing modern parties. These parties are usually led by local ulema and clerics who have identities and power bases outside the party and access to the educational and religious institutions and command greater public engagement. However they have not been able to gain national support in their lack of pluralistic and ethnic approach, a factor Muslim democrats and left-wing secular-styled parties have successfully leveraged. Seen with the lens of civic engagement it would not be wrong to conclude that Islamist parties leverage greater civic engagement in charitable as well communal aspects but fail to politically engage people because of sectarian and ethnic differentiations. Two parties that have successfully politically mobilized masses are Bhutto and the People's Party in the late 1960s and the like Muttahida Quami Movement in the 1980s. They owed their success to a political platform which effectively combined populism with a radical antiestablishment platform and appeal to ethnic sentiments. Muslim Democrats on the other hand, have been able to wield greater support in 1999 and 2013 with their overt allegiance to Islam combined with populist and ethnic strategies.

Islam is a great influence in Pakistani society. Pew Research Centre study noted that Pakistani Muslims overwhelmingly welcome Islamic influence over their country's politics. When asked how important is religion in life for them $92.7 \%$ replied it was 'Very Important'. Nearly $88 \%$ of those who see Islam playing a large role say that is a good thing. Similarly, $79 \%$ of those who say Islam's role is small say that is a bad thing for their country. It is interesting therefore that the people have preferred to vote for middle strategic Muslim democrats despite the presence of alternative right Islamist political parties. $82.4 \%$ people favor making the Sharia the official law in Pakistan, however most people equate Sharia as a sort of code for a better, easily accessible, honest and simpler version of official justice without the knowledge of details of exact Sharia. (Lieven March 2012) The same survey asked the respondents how would they rate Islamic political parties compared to other political parties and only $27.4 \%$ rated them 
better than other political parties. These finding assert my previous observation that Pakistanis despite being inclined to religion do not exhibit absolutist Islamic commitment.

Drawing from a comprehensive analysis of voting behavior by Haroon it is observed that political civic engagement in Pakistan at the national level is guided by personal and community patronage and at the local level citizens are connected by religious and social group ties. (Ullah 2014)

\section{Lost in Translation}

Pakistan's military rulers, as well as their civilian counterparts, have traditionally appealed to Islamic ideology to manipulate and manage ethnic, sectarian, and linguistic schisms in society. This deliberate maneuvering has its repercussions. Terrorism as an unwanted consequence of the increase in relative denomination of Islam has jarred the country. The government's inefficiency in providing basic services has left gaps which are filled by Islamic organizations especially in public education. Since decades mosques have acted as community meeting places which has also led to the ascendency of clerics and ulema in setting a public discourse and identifying social norms.

Pakistan's constructed identity emphasizes religion undermining ethnic, linguistic and sectarian diversity of a complex society. As a result, the country's approach to national security has been driven by ideological rather than pragmatic considerations. This was consequential in growth of 'Jihadism' which was used as a contrivance to keep external forces at bay. Fall of Dhaka in 1971 reinforced the paranoia that India and powerful forces aim dismemberment of Pakistan. Jihadism led to a growth of extremism and now more than 33 militant groups are operating on Pakistani soil. Shielded by their alliance with the military, extremist groups openly preach and recruit for their parochial political agendas, breeding intolerance and extremism in the society at large. Places like the 'Red Mosque' in the heart of the capital Islamabad exude hatred openly and have become breeding grounds of terrorism. There are Madrassas in Pakistan that educate the children not for better lives here in this world but for better lives in heaven. A mindset that drives these young people to go to extreme levels to implement their own ideologies.

The results have been devastating. Since 2003 terrorists have bombed Shia and Amadi mosques and over 800 schools. They have targeted naval and air force bases in Karachi, the Kamra, the Karachi International Airport and event the army's General Headquarters killing 19,917 civilians and 6024 security personnel.(Portal n.d.)

Extremist Islamists and jihadists have benefited from Pakistan's self-definition as an Islamic state. Given the centrality of Islam in Pakistan's national identity, secular leaders find it difficult to create national consensus against groups that describe themselves as 
soldiers of Islam. The ambivalent attitude of Pakistan's military towards the militant groups has made them powerful and there is still no comprehensive approach to contain or fight these terrorist groups. The progressive elements of the society are marginalized and the civil society is still weak and disorganized, driven apart by fear of the Taliban and the harsh gaze of the intelligence agencies. This is also true for the balanced sections of the Islamic Civil Society which condemn radical approach to religion but are either afraid to be vocal or find it in their benefit to silently support extremism. A study by WORDE highlighted that numerous faith- based Organizations challenge the validity of the use of violence by denouncing attacks on innocent civilians. They detract the credibility of militant groups by challenging them at an ideological level (WORDE October 2012). It would not be erroneous to say that the Islamic narrative was hijacked by groups who use religion as a means to gain dominion and engage in class warfare. The lack of democratic culture has weakened the capacity of citizens to engage collectively in denouncing the extremist ideology.

The problems are confounded when a practice of logical reasoning and critical questioning are widely discouraged. Debate in Islam has been harshly curtailed specially by the laws such as the blasphemy law. Anyone who questions the authority of the Ulema is given the title of infidel. The self professed claim of certain clerics that argument and questioning have no place in Islam has led to an unchallenged hegemony of various clerics. The problem is exacerbated as there is no single faction. Currently in Pakistan there are more than 50 schools of thought of Islam and even more religious organizations all of which differ in their explanations and interpretations. An environment of intimidation makes it difficult for any Muslim to question the decrees and fatwa issued by the so called contractors of Islam.

The country direly needs a counter narrative for the Islamic fundamentalism. For a country like Pakistan where religion is basis of social action; the answer can be derived from the religion only. Propagation of secular values will not prove effectual to counter fundamentalism. Just as we see an open debate and rise in awareness in political scenario of the country, it is necessary that the understanding of Islam be also open to debate. A mature understanding of religion will help us eliminate differences. It will encourage the expression of disagreements in public discourse rather than using violence, force and chaos. It will require rebuilding of Islamic institutions and also address the cultural habits and artifacts that have been embedded in its social fabric for decades. An unreformed education curriculum continues to promote religious intolerance and xenophobia, as do the madrasas and religious schools that flourish in the absence of a credible public education sector.

The state has an immense responsibility to rescue the country from this adversity by gradually embracing a new national narrative. A reformed education system that 
incorporates citizenship education, promotes liberal democracy and religious tolerance is the only solution.

\section{References}

Ahmad, Sadaf. (2008). "Identity Matters, Culture Wars: An Account of Al-Huda (re) Defining Identity and Reconfiguring Culture in Pakistan." Culture and Religion: An Interdisciplinary Journal vol.9:1, pp.63- 80.

Andrabi, Tahir \& Das, Jishnu \& Khwaja, Asim Ijaz \& Zajonc, Tristan, (2005). "Religious School Enrollment in Pakistan: A Look at the Data," Policy Research Working Paper Series 3521, The World Bank.

AKDN. (2000). Philanthropy in Pakistan: A Report of the Initiative on Indigenous Philanthropy in Pakistan. Karachi: Aga Khan Development Network.

Ali, Saleem H. (2009). Pakistan'S Madrassas: The Need for Internal Reform and the Role of International Assistance. Policy Briefing Paper, Brookings Doha Center.

Development in Pakistan. (2008). Working Paper No. 24, Birmingham: Religions and Development.

Fukuyama, Francis. (2001). "Social Capital, Civil Society and Development." Third World Quarterly, vol.22:1, pp.7- 20.

Future Issues. (June 2003). "Conference Paper No 47. Karachi: Social Policy and Development Center.

Goldberg, Chad Alan. (2001). "Social Citizenship and a Reconstructed Tocqueville." American Sociological Review, vol.66: 2, pp.289-315.

Haider, Zaid. (2011). "Ideologically Adrift." In Pakistan; Beyong the Crises State, by Ed. Maleeha Lodhi, Karachi: Oxford University Press, pp.113- 130.

Huntington, Samuel P. (2002). The Clash of Civilizaions and the Remaking of the World Order 2 ed. London: The Free Press.

Iqbal, Muhammad Asif and Siddiqui, Saima (2008). Mapping the Terrain: The Activities of Faith-Based Organisations in Development in Pakistan, Working Paper, University of Birmingham, Birmingham, UK. 
Kamali, Masoud. (2001). "Civil Society and Islam: a sociological perspective." European Journal of Sociology, vol.42, pp.457-482.

Lieven, Anatol. (March 2012) Pakistan: A Hard Country. NewYork: Public Affairs.

M. A. Iqbal, H. Khan, S. Javed. (2004). Non Profit Sector in Pakistan; Historical Background. SPDC Working Paper No. 4, Karachi: SPDC.

Marco Mezzera, Safiya Aftab. (2009). Pakistan State-Society Analysis. Democratization and Transnational Justice Cluster, Country Case Study: Pakistan, Initiative for Peace Building.

Nasr, Seyyed Vali Reza (2001). Islamic Leviathan; Islam and the Making of State Power. Oxford University Press, UK.

Nasr, Seyyed Vali Reza (1994). The Vanguard of Islamic Revolution; The Jam'at e Islami of Pakistan, University of California Press, London.

Nasr, Seyyed Vali Reza (2009). Forces of Fortune: The Rise of the New Muslim Middle Class and What it Will Mean for Our World. Free Press.

Noman, Omar. (1990). Pakistan: A Political Economy Since 1947, London: Kegan Paul International.

Norton, Augustus. (1993). "The Future of Civil Society in the Middle East." Middle East Journal, vol.47:2, pp.205-215.

Pasha, Aisha Ghaus \& Iqbal, Muhammad Asif (2002). Non-profit Sector in Pakistan: Government Policy and Future Issues, The Pakistan Development Review, vol. 41:4, Part II, pp. 879-908

Portal, South Asia Terrorism. Fatalities in Terrorist Violence in Pakistan 2003-2014, http://www.satp.org/satporgtp/countries/pakistan/database/casualties.htm (accessed December 27, 2014).

Qadeer, M. Abdul. (2006). Pakistan; Social and Cultural Transformations in a Muslim Nation, NewYork: Routledge.

Qadeer, Mohammad. (1997). "The Evolving Structure of Civil Society and the State in Pakistan." The Pakistan Development Review, vol.36:4, pp.743-762. 
Shah, Aqil. (2004). "Pakistan: Civil Society in the Service of an Authoritarian State." In Civil Society and Political Change in Asia, by Ed. Muthiah Alagappa, Stanford, California: Stanford University Press, pp.357-388.

SPDC. (2002). Dimensions of Non Profit Sector in Pakistan. SPDC Working Paper No. 1, Karachi: Center for Civil Society, Johns Hopkins University.

Tina Nabatchi, John Gastil, C. Michael Weiksner, Matt Leighninger. (eds.) (2012). Democracy in Motion. New York: Oxford University Press.

Ullah, Haroon K. (2014). Vying for Allah's Vote; Understanding Islamic Parties, Political Violence, and Extremism in Pakistan, Washington DC: Georgetown University Press.

USAID. (2011). The 2012 CSO Sustainability Index for Pakistan. Karachi: USAID.

WORDE. (2012). Pakistan's Civil Society: Alternative Channels to Countering Violent Extremism. Washington, DC: World Organization for Resource Development and Education.

Ziadi, S. Akbar. (2008). "An Emerging Civil Society?" Journal of Democracy: vol.19:4, pp.38-40.

Sumrin Kalia is Research Scholor in the Department of Public Administration, University of Karachi.

Prof. Dr. Khalid Mahmood Iraqi is Dean, Faculty of Management and Administrative Sciences, University of Karachi. 